\title{
Foreword
}

\section{Hayden White}

It is a great honor to be invited to present this collection of Reinhart Koselleck's essays and addresses. Some Anglophone readers will already know his Futures Past, a seminal work of historical theory. This collection of essays is much more far-ranging and evidences Koselleck's status as one of the most important theorists of history and historiography of the last halfcentury. Koselleck's work has implications for contemporary cultural studies that extend far beyond discussions of the practical problems of historical method. He is the foremost exponent and practitioner of Begriffsgeschichte, a methodology of historical studies that focuses on the invention and development of the fundamental concepts (Begriffe) underlying and informing a distinctively historical (geschichtliche) manner of being in the world.

If this formulation of Koselleck's project seems somewhat intimidatingly Hegelian to Anglophone sensibilities, it is because his work is itself deeply grounded in the tradition of Geisteswissenschaften that extends from Kant and Hegel through Marx, Dilthey, and Nietzsche, down to Weber, Heidegger, and Gadamer. But there is nothing insular about Koselleck's work. He has a profound knowledge of the British, American, and French contributions to philosophy of history, and he takes the whole sweep of European history, from the Greeks to the present, as his field of inquiry.

It is, however, to the study of the concept of history itself that Koselleck has devoted most of his scholarly life. It is not that Koselleck treats history's concept as some kind of Platonic paradigm against which every individual "idea" of history can be measured. On the contrary, he believes that the notion of history itself had a long period of historical development, extending from Herodotus to Gibbon, before it achieved conceptualization as a fundamental mode of human existence in the nineteenth century. Before this epoch, men certainly possessed a number of ideas about 
"history," viewing it as a method of research ("inquiry"), a place ("the past"), a process (temporality), a practice (memorialization, celebration, remembrance), a literary or, more precisely, rhetorical genre (history writing), and even a manifestation of an ontological category (humanity). But they did not, on the whole, or except very rarely (as in Vico), conceive a difference between natural temporality and historical temporality which, according to Koselleck, is crucial for understanding the role played by the concept of history in the identity of modern European society and culture.

For Koselleck, the modernity of our epoch differs from all of the other modernities of past epochs of social transformation, technological revolution, and cultural renaissance by virtue of European culture's achievement of "the concept of history." While European culture has always been characterized by a sense of history, a sense of having a history, a sense of being a historical phenomenon, only in its modern phase-sometime between 1750 and 1850 - did European society begin to think and act as if it existed in history, as if its "historicity" was a feature, if not the defining feature of its identity. So Koselleck argues, and the essays in this collection so ably translated by Todd Presner and his colleagues bear out this contention with impressive force and amplitude.

These essays should not be thought of, however, as a contribution to "philosophy of history" in the speculative and prophetic mode of Hegel, Marx, and Spengler. They are intended, rather, as contributions to the theory of history, without which, Koselleck insists, historical studies must remain something less than a true science even if they continue to produce more and more truthful information about the past.

Modern professional historical studies were born in the nineteenth century - of a desire for a knowledge of the past free of all theological, metaphysical, and ideological preconception and productive of detailed information about the natures of those peoples aspiring to nationhood in the wake of the French Revolution. History was to be studied in an objective and disinterested manner in order to construct a picture of historical reality by which to measure the falsity of various ideological constructions thereof. But since ideology was thought to be a result of theory overriding the gathering of information about the past-as witnessed by the nefarious effects of philosophy of history on social and political thought-historical studies remained caught on the horns of a dilemma: in order to become a science, they had to have a theory; but an interest in theory appeared to foreclose 
that interest in particular facts about the past on which historical studies was focused. The resolution of this dilemma was, however, implicitly contained within what came to be called the historist (or historicist) vision of historical reality, which posited historicity as not only a specifically social mode of being in the world but also a social mode of being in the world marked by a particular experience of temporality. Thus, the "content" of history could be grasped as social reality undergoing changes quite unlike those that mere nature underwent. Historical change could be seen to differ from natural change by its heterogeneity, multileveledness, and variability of rate of acceleration. With the discovery that the time of history was different from the time of nature, men also came to believe that historical time could be affected by human action and purposiveness in ways that natural time could not, that history could be "made" as well as "suffered," and that a historical knowledge true to its "concept" provided the prospects for a science of society that balanced the claims of experience with the insistencies of expectation, hope, and faith in the future.

Anglophone readers may have some difficulties with a few of Koselleck's key terms and especially with that of "concept." Permit me to try to unpack the term by contrasting it with some other terms occupying the same semantic field. Consider the phrase "the concept of history." This phrase can be differentiated from affine phrases such as "figure of history," "idea of history," "theory of history," "philosophy of history," and so on. Examples of figures of history would be mythical representations of the muse Clio, the Fates, or Destiny; Machiavelli's "fortuna," Walter Benjamin's "Angel of History," Hegel's "rose in the cross of the present," or the classical "historia magistra vitae." These are metaphorical expressions intended to bring the notion of history before the mind's eye by endowing it with the attributes of some conventionalized image or symbol.

An "idea of history," by contrast, would be an intuition (or perception) of historical phenomena submitted to rationalization by the application of categories of thought deemed adequate to their analysis. Thus, for example, Thucydides may be said to have had an idea of history different from that of Herodotus by virtue of the specific categories of thought he used to order his materials, assess conflicting accounts of the same phenomena, emplot his story, and present it in a manner uniquely his own. Thucydides uses many of the same categories used by Herodotus, but he adds a number of other categories - borrowed, for example, from Hippocratean medicine-in or- 
der to work up the materials of his subject and present its truth as different in kind from that of Herodotus. And so too for Polybius, Livy, Tacitus, Orosius, Commynes, and Salutati, down through Machiavelli and Guicciardini, Scaliger, Bayle, Voltaire, and Gibbon. Each of these historians brings to his labors a different "idea" of history-considered as a sequence of actions and events occurring in a given space over a given span of time-by which to distinguish between what will count as a historical as against some other kind of event, between significant or important events and insignificant or unimportant events, and between truthful accounts of these events and a merely imaginary, fictional, mythical, duplicitous, or simply erroneous account thereof.

What none of these purveyors of "ideas" of history provides, Koselleck suggests, is a proper "concept of history," by which he means a model of a structure of logical relationships by which to distinguish between a properly historical account of reality and a nonhistorical or ahistorical or antihistorical account thereof. A concept of history will specify the common content of all of those ideas of history informing the works of the master historians of the world: the content of history's subject matter, on the one hand, and the content of the forms of historical writing, on the other. A concept of history will identify the shared contents of all the ideas of history that have contributed to the definition of a distinctively historical way of knowing reality as history.

I will not further block the reader's access to the essays that follow, and that spell out all of this in persuasive detail, but will only add that, in general, Koselleck's theory of the concept of history features the following theses.

First, historical process is marked by a distinctive kind of temporality different from that found in nature. This temporality is multileveled, is subject to differential rates of acceleration and deceleration, and functions not only as a matrix within which historical events happen but also as a causal force in the determination of social reality in its own right.

Second, historical reality is social reality, an internally differentiated structure of functional relationships in which the rights and interests of one group collide with those of other groups and lead to the kinds of conflicts in which defeat is experienced as an ethical failure requiring reflection on "what went wrong" in order to determine the historical significance of the conflict itself. Koselleck makes the interesting argument that historical knowledge 
(as against information about the past) is driven forward by the kind of theoretical reflection to which the vanquished in a conflict of world historical significance may be driven (he cites Thucydides, Tacitus, Machiavelli, and Niebuhr as cases in point) by the need to ask "What went wrong?" or: What is the nature of historical reality, that the best laid schemes of mice and men so often go astray? In the domain of historical theory, Koselleck tells us, nothing succeeds like failure in a combat in which both sides feel they represent the right. The victorious have little reason for theoretical reflection. At most, they only need to know the facts. The vanquished, on the other hand, must inquire into the nature of a reality that permits expansive hope only to dash it to despair. Thus, the pattern of "rise and fall" is intrinsic to a genuinely historical thinking, but another pattern, that of "progress," is discernible to the historical consciousness capable of distinguishing between a defeat and the new knowledge of reality that the experience of defeat makes possible.

Thirdly, a critical historical consciousness is born of an awareness of a gap between historical events and the language used to represent themboth by the agents involved in these events and by historians retrospectively trying to reconstruct them. Awareness of the disparity between language and historical reality is the basis of history's prime auxiliary discipline, source criticism (philology, paleography, diplomatic, heuristics, hermeneutics in general). It is also the basis of the recognition that every historical account is a construction in discourse of past reality rather than simply a translation of the facts contained in the evidence into contemporary language. The disparity between our experience of reality and the language we have available for representing both this reality and this experience is what infuses the concept of history with the realization that history is an open-ended process rather than a closed science and a fatality. The critical historian must proceed on the basis of the realization that she has to invent a language adequate to the representation of historical reality for her own time and place of work.

The history of historiography, in Koselleck's view, is a history of the evolution of the language of historians, a language that is ever more conceptually self-conscious, ever more aware of the difficulty of grasping the experience of others in terms adequate to its reality. In this respect, Koselleck's work converges with that of Barthes, Foucault, and Derrida, all of whom have stressed the status of historiography as discourse rather than as 
discipline and featured the constitutive nature of historical discourse as against its claims to literal truthfulness.

Finally, and this is the fourth aspect of Koselleck's notion of the concept of history, a properly historicist concept of history will be informed by the realization that what we call "modernity," "modernization," and "modernism" are nothing other than aspects of the discovery of history's concept in our age. The Enlightenment program of modernization, with its expectations about the possibility of bettering society through the progressive extension of the hegemony of reason, science, and technology over nature and culture, presupposes the concept of history as its condition of possibility. Our difference from all earlier eras and epochs of our history consists precisely in the belief that we exist in history understood as a process of progressive development in which both society and our knowledge of it are historical in nature. The aporias of modernism-in arts and letters as well as in the human and natural sciences-are a function of the discovery of the historicity of both society and knowledge.

The idea that our knowledge is subject to the same rule of evolution as our objects of study generates a kind of relativism, to be sure, insofar as epistemic validity has to be seen as grounded in the time, place, and social circumstances of its production. But Koselleck insists that this relativism provides no grounds for nihilism or a crippling skepticism. Historical relativism, he concludes, avoids Pyrrhonism by virtue of its substitution of the relative certainty of the knowledge we can have of our society and culture for the absolute certainty promised by all forms of idealism. The concept of history includes a concept of historical knowledge that knows itself to be always provisional and open to revision. As historical knowledge dissolves the myths, lies, and falsifications of history, it secures a stable base from which to assess and augment that "space of experience" in which men build a notion of a human reality that is both always changing and ever more becoming itself. 
THE PRACTICE OF CONCEPTUAL HISTORY 
